\title{
Effect of feeding fat on fibrinolysis, stypven time, and platelet aggregation in elderly Africans
}

\author{
J. C. FERGUSON, N. MACKAY, AND G. P. McNICOL
}

From Makerere University College Medical School Extension, Nairobi, and the University Departments of Medicine (Royal Infirmary) and Materia Medica, Stobhill Hospital, Glasgow

SYNOPSIS The effects of acute fat feeding on fibrinolytic activity, platelet aggregation, and stypven time in six elderly Africans are presented. These indicate that there is no alteration in the pattern of response seen in Africans with advancing age.

Acute fat feeding in Europeans leads to shortening of the stypven time and inhibition of plasma fibrinolytic activity; there is also inhibition of platelet aggregation (Dubber, Rifkind, Gale, McNicol, and Douglas, 1967). A further study (Ferguson, MacKay, and McNicol, 1970) demonstrated that in Africans and Asians, although there was comparable reduction in the stypven time with acute fat feeding, there was no inhibition of fibrinolytic activity. Platelet aggregation, as measured by the Chandler tube technique, also was not influenced in Africans and Asians.

The Europeans previously studied were in the third and fourth decades and the Africansand Asians were all in the third decade of life.

The present investigation was carried out to find out if there was any change in response to fat feeding in elderly Africans and in particular to see whether or not they had moved towards the pattern of response seen in Europeans.

\section{Subjects, Materials, and Methods}

The group studied consisted of six African males, all of whom were elderly, and, although their ages could not be measured accurately on the basis of remembered events, three were at least in the fifth decade and three in the sixth decade. In contrast to the groups previously studied who had a 'European' diet (Ferguson et al, 1970) this present group had a normal African diet, low in animal protein and fat.

Each subject was investigated twice, once after a low fat breakfast, the control situation, and again after the same breakfast to which had been added Requests for reprints should be addressed to Dr J. C. Ferguson, Department of Materia Medica, University of Glasgow, Stobhill Hospital, Glasgow.

Received for publication 17 February 1972.

\begin{tabular}{lccc}
\hline Breakfast & Low Fat & High Fat \\
\hline Carbohydrate $(\mathrm{g})$ & 62.9 & $71 \cdot 0$ \\
Protein & $(\mathrm{g})$ & 4.0 & $10 \cdot 2$ \\
Fat & $(\mathrm{g})$ & 0.6 & $95 \cdot 1$ \\
\hline
\end{tabular}

Table Content of both types of breakfast

$270 \mathrm{~g}$ double cream. The details of the breakfast are provided in Table I. The fatty meal has been shown previously (Dubber et al, 1967; Ferguson et al, 1970) to produce significant elevation of the levels of serum triglyceride, phospholipid, and plasma free fatty acid.

The subjects fasted and refrained from smoking from the previous evening and after the breakfast a further three-hour fast was observed and venous blood samples were then taken. Before venepuncture each subject was rested for 20 minutes. The order in which the breakfasts were taken was randomized.

Venous blood, obtained with minimal occlusion of the circulation, in plastic syringes after a clean venepuncture using a needle of gauge no. $19,27 \mathrm{ml}$, was placed in $9 \mathrm{ml}$ amounts in chilled siliconized centrifuge tubes, each containing $1 \mathrm{ml}$ of $3.8 \%$ sodium citrate for fibrinolytic coagulation and plate- $\sigma$ let aggregation studies, and $2.5 \mathrm{ml}$ was mixed in a $\mathrm{N}$ sequestrene container (Stayne Laboratories Limited, High Wycombe) for platelet counts. The citrated silicone specimens were kept in ice and centrifuged 10 minutes after collection $(600 \mathrm{~g}$ for five minutes at $4^{\circ} \mathrm{C}$ ) to obtain platelet-rich plasma.

EUGLOBULIN CLOT LYSIS TIME

This was measured by the method of Nilsson and Olow (1962). Since fibrinolytic activity is proportional to the reciprocal of the lysis time (Sherry and Alkjaersig, 1957), the results are expressed as units of activity, the reciprocal of a lysis time of 300 
minutes being taken as 1 unit (Sherry, Lindemeyer, Fletcher, and Alkjaersig, 1959). This test was designed to measure plasma plasminogen activator level.

\section{PLATELET AGGREGATION}

This was measured by a Chandler's tube technique, modified to use platelet-rich plasma rather than whole blood. One $\mathrm{ml}$ of platelet-rich plasma was diluted with $2.5 \mathrm{ml}$ of $0.9 \% \mathrm{NaCl}$ and recalcified with $1 \mathrm{ml}$ $0 \cdot 25 \mathrm{M} \mathrm{CaCl}_{2}$.

\section{PLATELET COUNT}

This was performed by the method of Dacie (1956).

STYPVEN (RUSSELL'S VIPER VENOM) TIME

This was measured by a modification of the method of Maclagan, Billimoria, and Curtis (1958). The plasma used was that collected in siliconized tubes and centrifuged at $600 \mathrm{~g}$ for five minutes at $4^{\circ} \mathrm{C}$. It was further centrifuged at $2000 \mathrm{~g}$ for 15 minutes at $4^{\circ} \mathrm{C}$ to render it platelet-poor. To $0.1 \mathrm{ml}$ of this plasma in a glass test tube at $37^{\circ} \mathrm{C}$ were added simultaneously $0.1 \mathrm{ml}$ stypven (Burroughs Wellcome Co.) and $0.1 \mathrm{ml} 0.025 \mathrm{M} \mathrm{CaCl}_{2}$, and the clotting time was recorded.

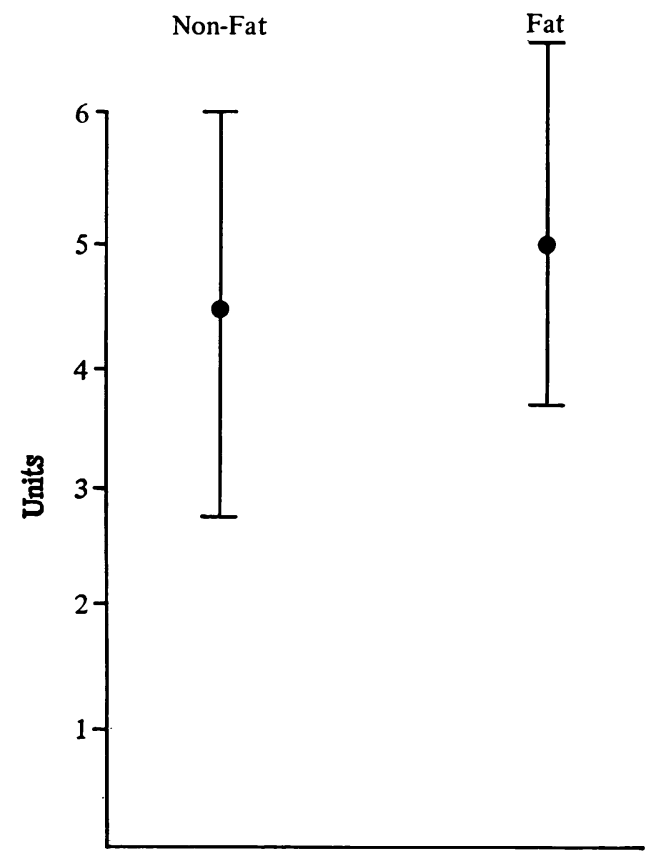

Fig. 1.

\section{Results}

\section{EUGLOBULIN CLOT LYSIS}

These are shown in Figure 1. The values are of the same order as those of the younger Africans previously studied $(4.34 \pm 0.81$ after the low fat breakfast and $4.22 \pm 0.83$ after the high fat breakfast (Ferguson et al, 1970) and show no significant change following the high fat meal $(t=1 \cdot 19, \mathrm{P}>0 \cdot 2)$.

\section{PLATELET AGGREGATION}

The results are shown in Figure 2. There is no significant change $(t=1 \cdot 77, P>0 \cdot 2)$.

\section{PLATELET COUNT}

These values are shown in Figure 3. No significant difference was noted in platelet counts after the control breakfast as compared with the test breakfast.

\section{STYPVEN TIME}

These results are shown in Figure 4. There is a substantial and significant fall in clotting time after the fatty breakfast $(\mathrm{t}=3.67, \mathrm{P}<0.02)$.

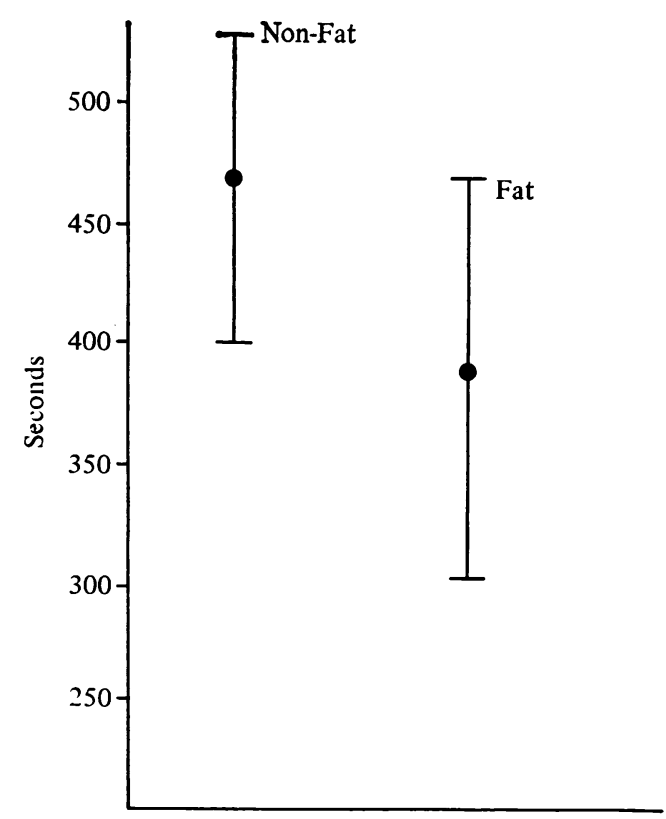

Fig. 2.

Fig. 1 Euglobulin clot lysis activity in units after each type of breakfast. Mean \pm standard deviation.

Fig. 2 Time in seconds to 'snowstorm' of platelet aggregation in the Chandler's tube. There is no significant difference between values following each type of breakfast. Mean \pm standard deviation. 


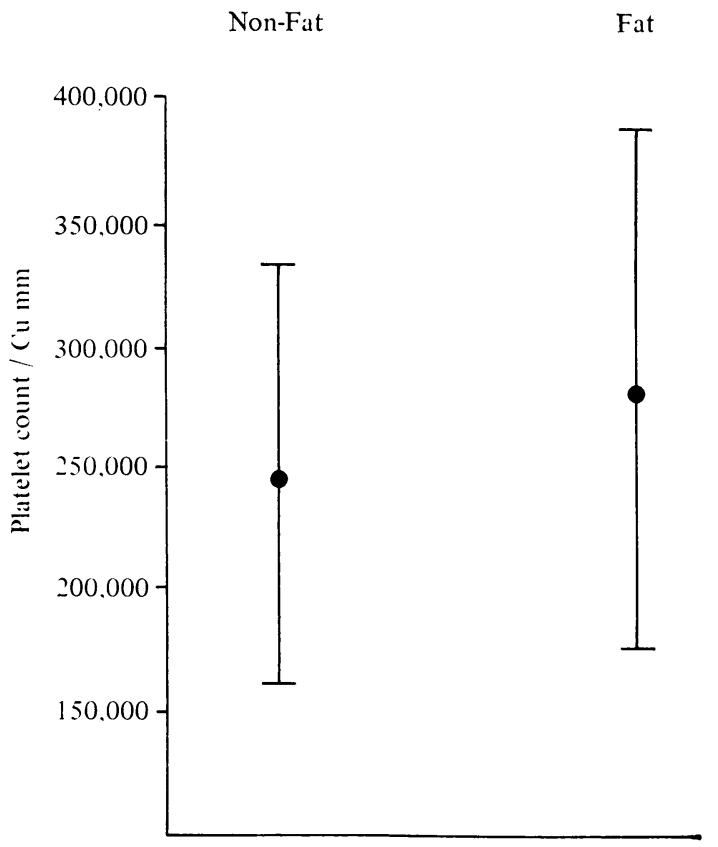

Fig. 3 Platelet counts after both types of breakfast. Mean $\perp$ standard deviation.

\section{Discussion}

These results show that elderly Africans have a similar response in fibrinolytic and coagulation mechanisms after fat feeding as was found in young Africans: in both groups fibrinolysis is not inhibited after fat feeding as it is in Europeans.

It has been demonstrated that fibrinolytic activity increases with age in Europeans (Fearnley and Lackner, 1955), and, although the numbers in this present study are small, the results suggest that this change does not occur in Africans.

Although the relationship between depressed fibrinolytic activity and atheromatous vascular disease is not clearly established, it is of interest that Africans who have been shown to have a very low incidence of vascular disease should have evidence of brisk fibrinolytic activity extending into the sixth decade of life.

Our thanks are due to Professor S. Alstead and Professor A. S. Douglas who played a major role in establishing laboratory facilities.

Financial assistance was provided by the Kenya

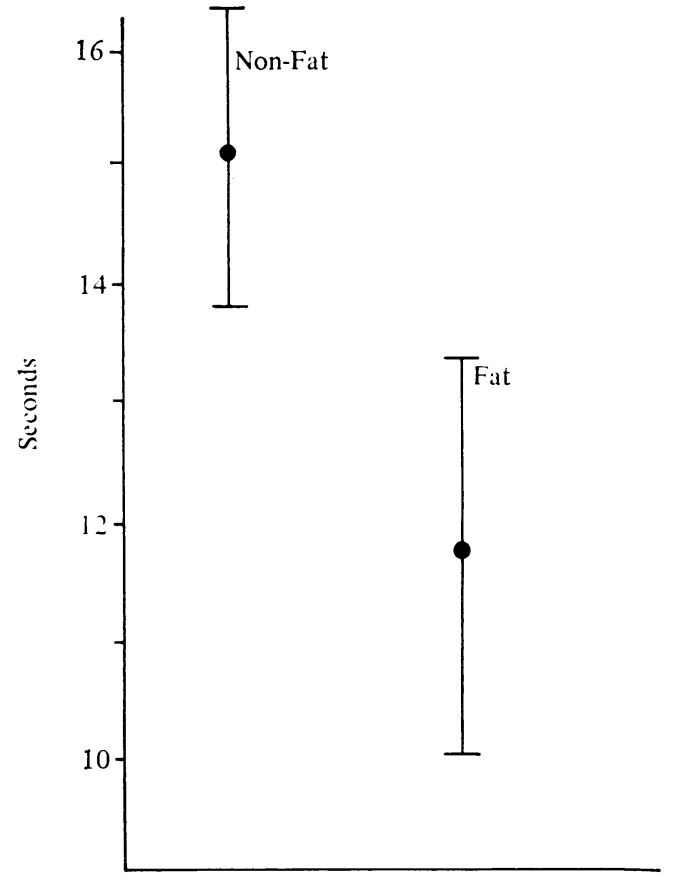

Fig. 4 Stypven times following both types of breakfast. Mean \pm standard deviation.

Ministry of Health, East African Medical Research Council, Ministry of Overseas Development, Hoechst (East Africa) Limited, Pfizers Tropical Research Laboratory, Merck, Sharp and Dohme Laboratories, Pfizer Corporation, and ICI Pharmaceutical Division. Reagents were provided by A. B. Kabi, Stockholm, Sweden.

\section{References}

Dacie, J. V. (1956). Practical Haematology, p. 37. Churchill, London. Dubber, A. H. C., Rifkind, B., Gale, M., McNicol, G. P., and Douglas, A. S. (1967). The effect of fat feeding on fibrinolysis, Stypven time and platelet aggregation. J. Atheroscler. Res., 7, 225-235.

Fearnley, G. R., and Lackner, R. (1955). The fibrinolytic activity of normal blood. Brit. J. Haemat., 1, 189-198.

Ferguson, J. C., MacKay, N., and McNicol, G. P. (1970). Effect of feeding fat on fibrinolysis, Stypven time and platelet aggre- $N$ gation in Africans, Asians, and Europeans. J. clin. Path., 23, 580-585.

MacLagan, N. F., Billimoria, J. D., and Curtis, C. (1958). Lipaemia $\sigma$ and blood coagulation with special reference to the Stypven technique. Lancet, 2, 865-869.

Nilsson, I. M., and Olow, B. (1962). Fibrinolysis induced by streptokinase in man. Acta chir. scand., 123, 247-266.

Sherry, S., and Alkjaersig, N. (1957). Studies on the fibrinolytic enzyme of human plasma. Thrombos. diathes. Haemorrh. (Stuttg.), 1, 264-288.

Sherry, S., Lindemeyer, R. I., Fletcher, A. P., and Alkjaersig, N. (1959) Studies on enhanced fibrinolytic activity in man. J. clin. Invest., 38, 810-822. 